\title{
Preliminary Test of Hydrocarbon Exposure on Lepironia articulate in Phytoremediation Process
}

\author{
Nadya Hussin AL Sbania ${ }^{1, a^{*}}$, Siti Rozaimah Sheikh Abdullaha ${ }^{1, b}$ \\ Mushrifah Idris $^{2, c}$, Omar Hamed Jehawi ${ }^{1, d}$, Nur 'Izzati Ismail', e
}
${ }^{1}$ Department of Chemical Engineering and Process, Faculty of Engineering and Built Environment, Universiti Kebangsaan Malaysia, Malaysia
${ }^{2}$ Tasik Chini Research Center, Faculty of Science and Technology, Universiti Kebangsaan Malaysia, Malaysia
aneam2009@yahoo.com, bctrozaimah@gmail.com, 'mushrifahidris@gmail.com, omerjehawi@yahoo.com, ezaty_ismail@yahoo.com,

Keywords: Phytoremediation; preliminary test; Diesel; Lepironia articulate; subsurface flow; free flow.

\begin{abstract}
The preliminary tests is physically and visually observed to estimate the concentrations of contaminants that can give negative effects on plants growth and at which concentration the plants can tolerate and survive. In this study, bulrush of Lepironia articulate was subjected to diesel to assess its ability to survive when exposed to diesel contaminants with different concentrations $(0$, $5,10,20,30,35$ and $40 \mathrm{~mL}$ diesel/L water). The investigation was conducted in 30 days with two flow systems, free surface (FSF) and sub-surface flow (SSF), were adopted to observe in which system the plant can tolerate to diesel better. These findings will be applied in future study of phytotoxicity test to assess its ability to phytoremediate polycyclic aromatic hydrocarbon (PAHs) contamination in wastewater. At the end of diesel exposure, the result indicated that the plant growth in SFS was better compared to FSF system. The plant had shown that it could only grow and survive in concentrations of $5,10,20,30,35$ and $40 \mathrm{~mL}$ diesel/L water in SSF and in concentrations of 5,10 and $20 \mathrm{~mL} / \mathrm{L}$ in FSF system. The results of this study will be a basis for future study that aims to study PAHs removal from water using L. articulate plants.
\end{abstract}

\section{Introduction}

Environmentally hazardous and the high cost of some conventional treatment processes has produced economic pressures and caused engineers to search for creative, cost effective and environmentally ways to control water pollution. Phytoremediation could be a sustainable remediation alternative for conventional remediation technologies [1]. It has several advantages: it can be applied in situ over large areas, with low cost, and the soil does not undergo significant damages [2]. This green technique is also easily accepted and often welcomed by the general public due to its significant improvement of the impacted landscape. The ability of plants to remove contaminants from the environment has been recognized and taken advantage of its applications such as land farming of waste [3]. Phytodegradation uses plants and microorganisms to break down organic pollutants in situ [4]. It includes several processes namely, phytoextraction, phytodegradation, hizofiltration, phytostabilization and phytovolatilization [5,2]. This technology is applicable to different contaminants, including metals and radionuclides, as well as organic compounds like chlorinated solvents, polychlori- biphenyls, polycyclic aromatic hydrocarbons, pesticides/insecticides, explosivesand surfactants [6]. There are many researchers who had proven the effectiveness of plants to remove contaminants from the soil, water and air. Abelmoschus moschatus, Eleocharis quisetina J. et C.Presl, Acacia confusa wild., andEucalyptus saligna, Ludwigia octovalvis and Scirpus grossus are particularly effective in translocating heavy metals to easily harvestable leaves and shoots [7,8]. The bulrush (Scirpus grossus) also can be effectively applied to phytoremediation of water contaminated with total petroleum hydrocarbon TPH [9]. 
The success of phytoremediation is dependent on a large number of factors, such as types and concentrations of contaminant, selection of appropriate vegetation, plant growth and survival, type of system (free surface (FSF) or sub-surface flow (SSF)) and site climate. So, a greenhouse study and pilot testing (preliminary test) is required before a full-scale system can be installed to ensure that the remedy is effectively performed by selected plants. A preliminary test in phytoremediation is necessary to determine the ability of plant to survive in media with different concentrations of contaminant. It is conducted to determine the maximum concentration of the contaminant that is harmful to plant and suppress its growth. High contaminant concentration may cause root damage. This has serious consequences for nutrient and water supply to aboveground plant parts [10]. In this work, we investigate the capability of Lepironia articulate to survive and grow in different concentration of diesel in two systems, sub surface flow (SSF) and free surface flow (FSF). Constructed SSF and FSF wetlands are being increasingly implemented worldwide into wastewater treatments [11]. The different between the SSF and FSF is the layer of water. FSF has a thin layer of water above the media whereas the water level of the SSF is kept just below the top of the media [12].

The diesel was chosen as hydrocarbon contaminants due to the presence of aromatic hydrocarbons (PAHs) such as benzene, toluene, ethyl benzene and xylene and it is more toxic to plants than crude oil [13]. Polycyclic aromatic hydrocarbons (PAHs) are ubiquitous pollutants in the environment and are derived from both man-made and natural resources [14]. PAHs is considered great threat to the environment and human beings due to their toxicity to the higher organisms and resistance to microbial attack [15]. The hydrophobic nature of PAHs makes their clean up extremely difficult and allows them to persist for longer periods [14].

Lepironia articulate (Fig. 1) is commonly known as grey sedge or krajood [16]. It has rhizome horizontally creeping and woody. Its shoot is cylindrical, greyish green, hollow and transversely septate. It belongs to the family Cyperaceae and is the margins of fresh water swamps, and swamp forest [4].

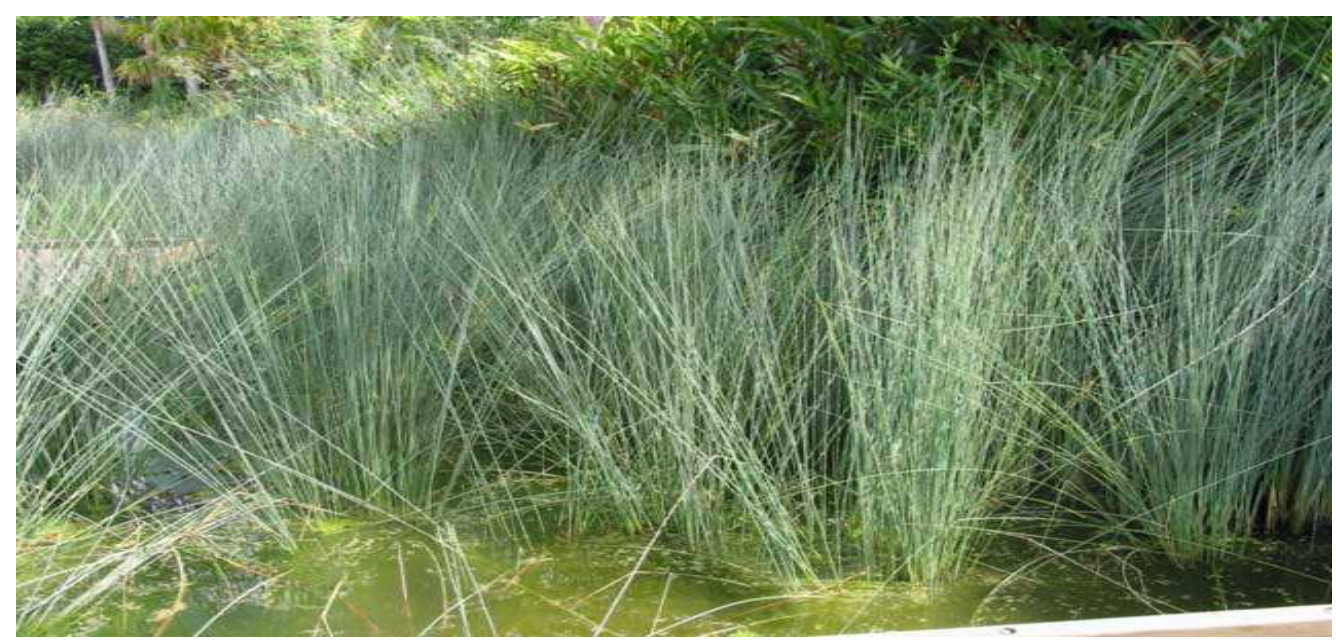

Fig. 1: An image of Lepironia articulate.

\section{Materials and method}

First, synthetic wastewater was prepared by mixing water with different diesel concentrations $(0,5,10,20,30,35$ and $40 \mathrm{~mL}$ diesel/L water). Secondly, three healthy bulrush plants of Lepironia articulate were planted in 6 pails each filled with $3 \mathrm{~kg}$ of sand (SSF and FSF). Next, synthetic wastewater was poured into the sand for both SSF and FSF systems which required 0.8 and $2 \mathrm{~L}$ of wastewater respectively. Throughout the exposure, addition of some water to the plants was done occasionally to ensure the plants having sufficient water to grow. Fig. 2 shows the different between SSF and FSF system. 


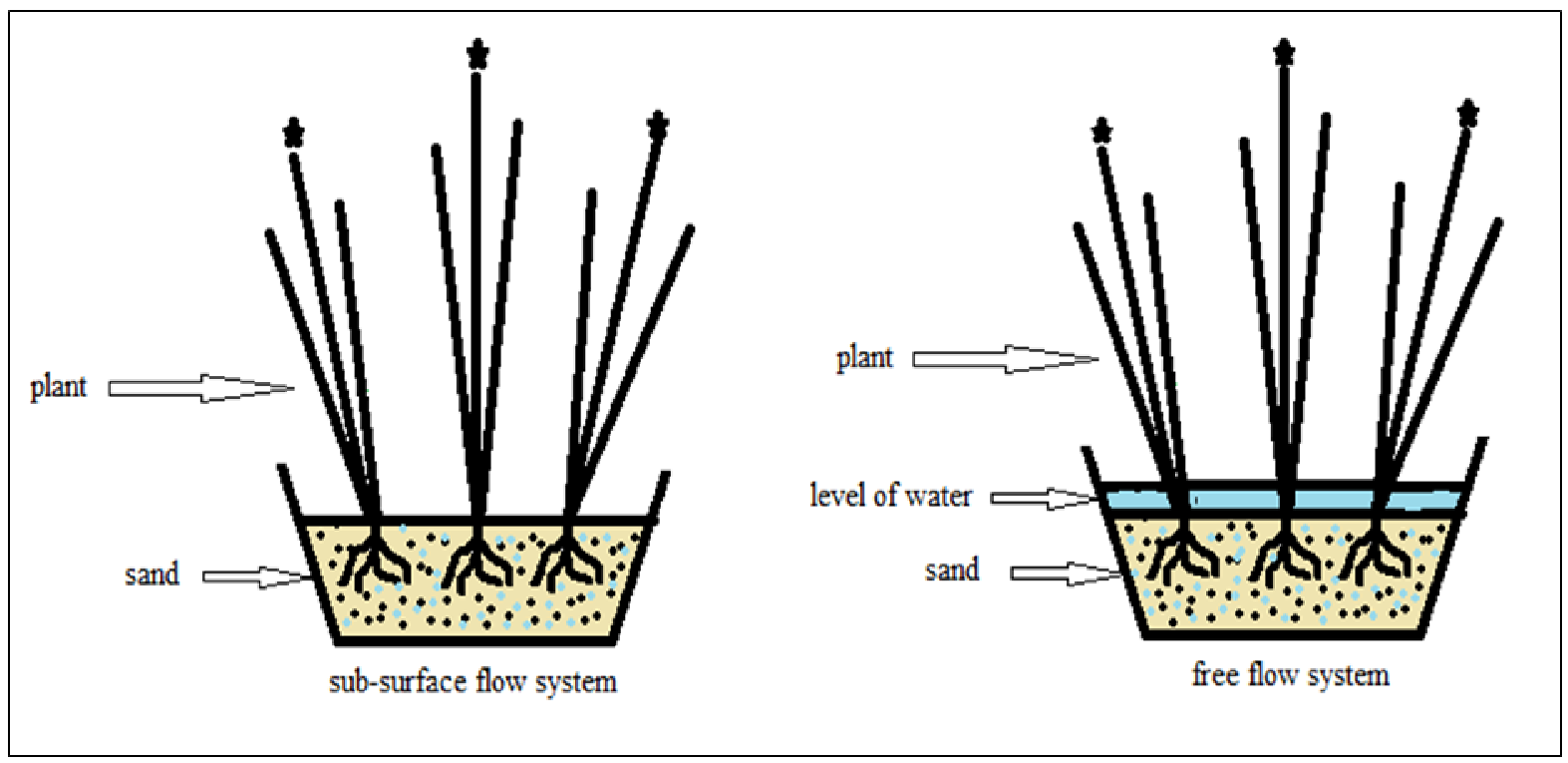

Fig. 2: The different between SSF and FSF system.

The plant growth was observed physically for 30 days in the the two systems (SSF and FSF) to investigate the ability of the plant to survive and resist the hydrocarbon contaminant. At the end of exposure period, the percentage of withered plants was determined using the following Eq. 1:

$$
\% \text { the percentage of withered plants }=\frac{\text { number of withered plant }}{\text { number of total plant }} \times 100
$$

Also, the number of died plants in each pail are recorded to determine the LC50 values. LC50 is defined as the concentration at which $50 \%$ lethal of the population of experimental organisms. The diesel concentration that results in $50 \%$ of the measured effect can be determined from the doseresponse relationship graph. The dose-response relationship describes the change in effect on an organism caused by different concentration exposure of contaminant [17].

\section{Results and Discussion}

After 30 days of exposure to diesel contaminants, the plant had shown that it could grow and survive in all diesel concentration $(0,5,10,20,30,35$ and $40 \mathrm{~mL} / \mathrm{L})$ in the subsurface flow system. As shown in Fig 3, all bulrush plants were still green in 0, 5, 10 and $20 \mathrm{~mL} / \mathrm{L}$, one bulrush withered in 30 and $35 \mathrm{~mL} / \mathrm{L}$ and two bulrushes were withered in $40 \mathrm{~mL} / \mathrm{L}$ as depicted in Fig 3.

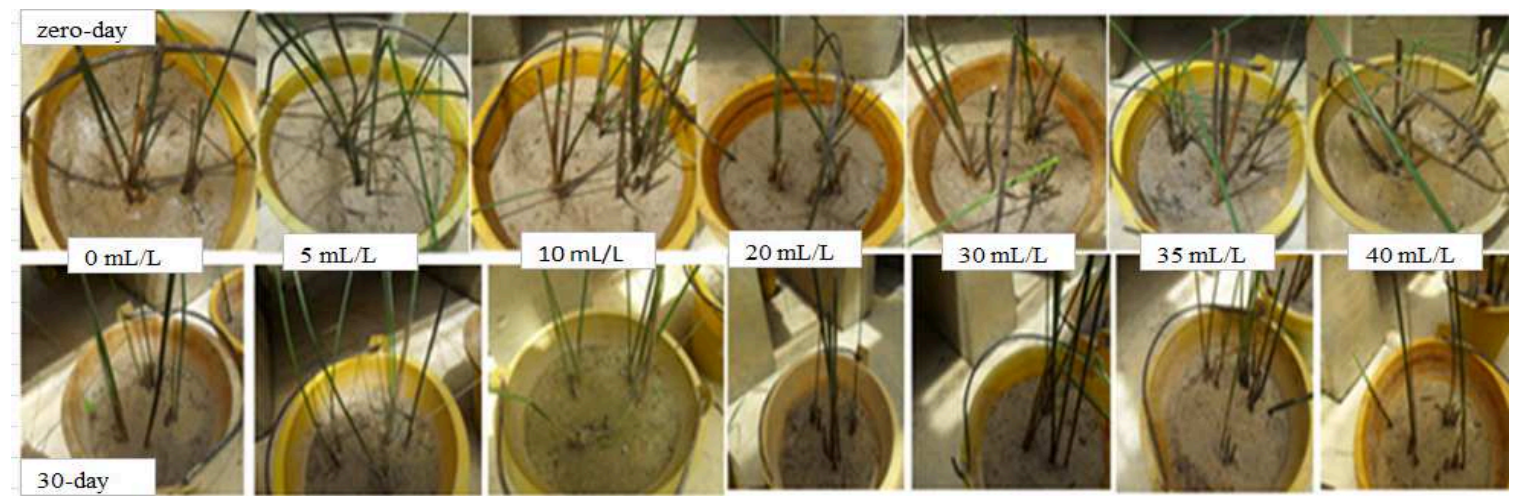

Fig. 3: Growth of Lepironia articulate in different diesel concentrations on day 30 in SSF systems.

In the free flow system, all bulrush plants could grow and survive in 0 and $5 \mathrm{~mL} / \mathrm{L}$, two bulrushes were withered in 10 and $20 \mathrm{~mL} / \mathrm{L}$ but all died in 30,35 and $40 \mathrm{~mL} / \mathrm{L}$ as shown in Fig 4. 


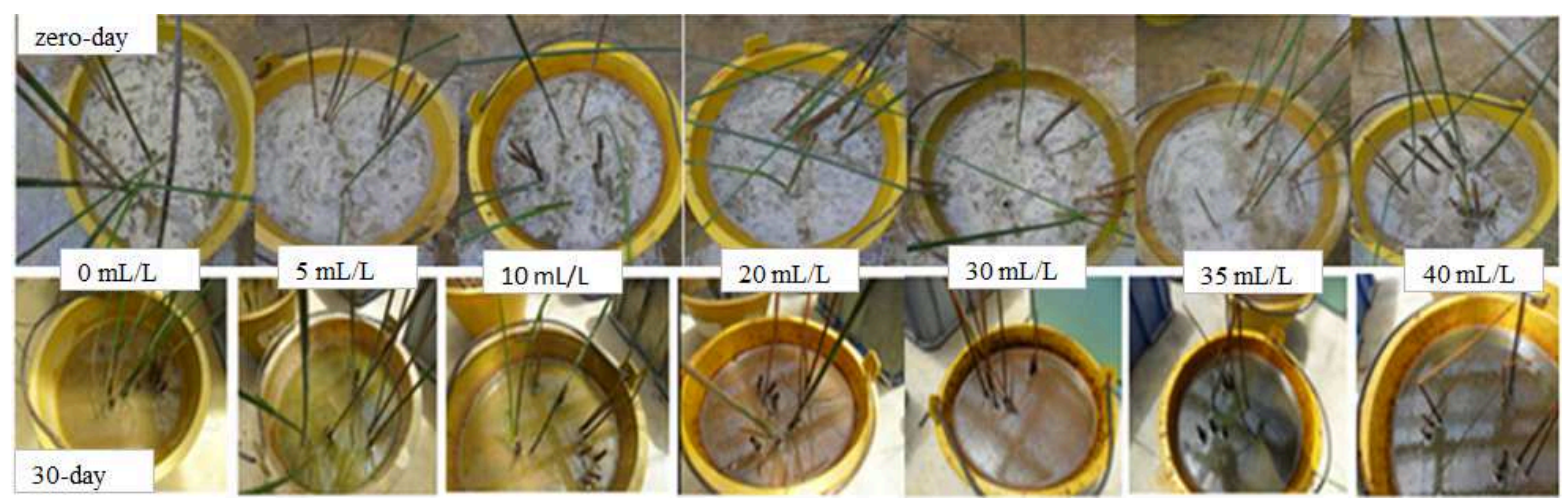

Fig. 4: Growth of Lepironia articulate in different diesel concentrations on day 30 in FSF systems.

The percentage of withered plants in each concentration was determined relative to the total number of plants in the pot. The number of withered plants was recorded, and their percentage was determined using Eq (1). As shown in Fig. 5, the withered plant percentage was $0 \%$ in 0,10 and 20 $\mathrm{mL} / \mathrm{L}, 33 \%$ occurring in 30 and $35 \mathrm{~mL} / \mathrm{L}, 66.7 \%$ in $40 \mathrm{~mL} / \mathrm{L}$ in SFS. In the free flow system, $0 \%$ of plants were withered in $5 \mathrm{~mL} / \mathrm{L}, 66 \%$ in 10 and $20 \mathrm{~mL} / \mathrm{L}$ and $100 \%$ withered in 30,35 and 40 $\mathrm{mL} / \mathrm{L}$.

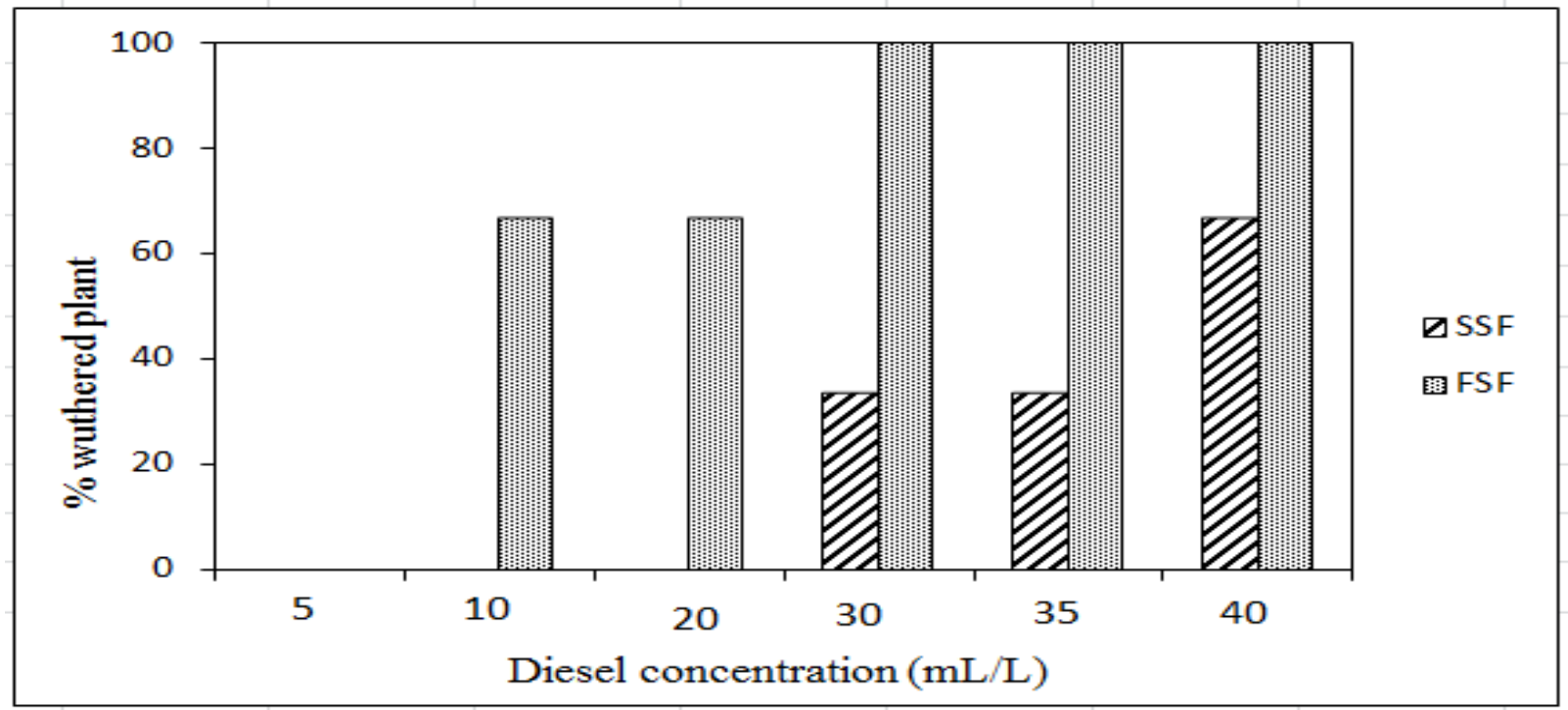

Fig. 5: Percentage of withered plants for SSF and FSF systems.

The dose-response curve plotted as a cumulative number of withered plants by each diesel concentrations used for SSF and FSF systems. The concentration effect of the diesel on the withered percentage of Lepironia articulate correlated as a linear regression $(\mathrm{R} 2=0.8426)$ and the range of $50 \%$ withered plants appears approximately at $39.2 \mathrm{~mL} / \mathrm{L}$ in SSF. In FSF (R2=0.7773) and the range of 50\% withered plants appears approximately at $14.16 \mathrm{~mL} / \mathrm{L}$ (Fig 6). 


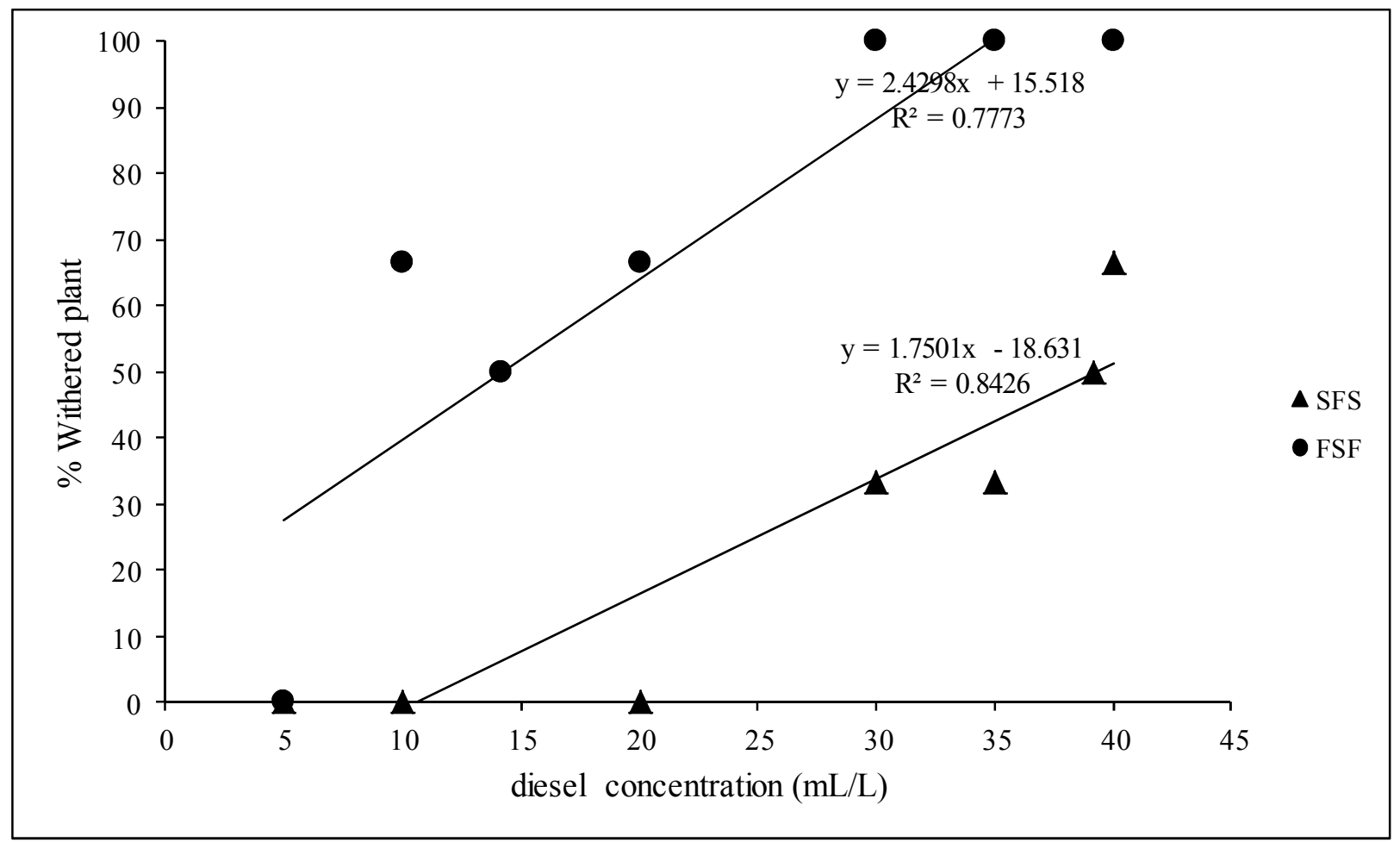

Fig. 6: Toxicity of Lepironia articulate concentration-response curve for 30 days for SFS and FSF systems

These results and calculations has indicated that the plant growth in SFS had performed better compared to the FSF system. This maybe due to no sticky layer preventing the arrival of oxygen to plant roots that is required by microbial degradation process.

\section{Conclusions}

Laboratory culture of preliminary experiments was conducted to assess the ability of Lepironia articulate to survive at different diesel concentration in two system exposure systems (SSF and FSF). The results clearly show that whenever the concentration increased the withered plant number also increased. The range of $50 \%$ withered plants was found at approximately $39.2 \mathrm{~mL} / \mathrm{L}$ concentrations in SFS and at $14.16 \mathrm{~mL} / \mathrm{L}$ in FSF. Therefore, diesel concentrations of less than 39.2 $\mathrm{mL} / \mathrm{L}$ in SFS and less than 14.16 in the FSF system will be considered for future phytotoxicity studies to ensure that plants are able to survive, as the value of $50 \%$ withered plants means that plants cannot survive and indicates that the diesel concentration was too high for this species.

Acknowledgement: The authors would like to thank Universiti Kebangsaan Malaysia (UKM-DLP2012-060) and Tasik Chini Research Centre for supporting this research project and the Higher Education Ministry of Libya for providing a doctoral scholarship for the first author.

\section{References}

[1] N. Witters, R. Mendelsohn, S. Van Passel, S. Van Slycken, N. Weyens, E. Schreurs,E. Meers, F. Tack, B. Vanheusden, J. Vangronsveld, Phytoremediation, a sustainable remediation technology? II: Economic assessment of $\mathrm{CO} 2$ abatement through the use of phytoremediation crops for renewable energy production, Biomass and Bioenergy. 39 (2012) 470-477.

[2] C. Camesellea, R. A. Chirakkarab, K. R. Reddyb, Electrokinetic-enhanced phytoremediation of soils: Status and opportunities, Chemosphere. 93 (2013) 626-636.

[3] Etim E. E, Phytoremediation and Its Mechanisms, Int. J. Environ. Bioener. 3(2012) 120-136. 
[4] P. Domyos. and S. Te-chato, In vitro propagation of Lepironia articulate in Kuan Kreng Peat lands, Nakhon Si Thammrat, Journal of Agricultural Technology. 6 (2013) 1595-1605.

[5] M. Azizur Rahman, H. Hasegawa, Aquatic arsenic: Phytoremediation using floating macrophytes, Chemosphere. 83 (2011) 633-646.

[6] A. M. Paz-Alberto and G. C. Sigua, Phytoremediation: A Green Technology to Remove Environmental Pollutants, American Journal of Climate Change. 2(2013)71-86.

[7] A. Ding, L. Cheng., P. Liu, P. J. Carpenter, and Y. Teng. Plant Response to Metal Contamination at an Oil Shale Tailing Site in Maoming, South China, National Ground Water Association. 27(2007)111-117.

[8] H. S. Titah, Sheikh S.R. Abdullah, M. N. Idris, Anuar, H. Basri and M. Mukhlisin, Phytotoxicity and Uptake of Arsenic by Ludwigia octovalvis in a Pilot Reed Bed System. Environmental Engineering Science. 31(2014) 71-79.

[9] I. A. Al-Baldawi, S. R. Sheikh Abdullah, F. Suja, Anuar N. and Idris M, A phytotoxicity test of bulrush (Scirpus grossus) grown with diesel contamination in a free-flow reed bed system, Journal of Hazardous Materials.15 (2013) 64-69.

[10] D. Godbold and A. Hüttermann, The uptake and toxicity of mercury and lead to spruce (picea abifs karst, seedlings. Water, Air, and Soil Pollution. 31( 1986) 509-515.

[11] T. K. Graczyk, F. E. Lucy, L. Tamang, Y. Mashinski, M. A. Broaders, M. Connolly and H. A. Cheng, Propagation of Human Enteropathogens in Constructed Horizontal Wetlands Used for Tertiary Wastewater Treatment, Applied and Environmental Microbiology. 75 (2009) 4531-4538.

[12] P. E. Lim, T. F.Wong, D. V. Lim, Oxygen Demand, Nitrogen and Copper Removal by FreeWater-Surface and Subsurface-Flow Constructed Wetlands under Tropical Conditions, Environment International. 26 (2001) $425 \pm 431$.

[13] I. A. Al-Baldawi,S.R.S. Abdullah, F. Suja, N. Anuar, \& M. Idris, Phytotoxicity test of Scirpus grossus on diesel-contaminated water using a subsurface flow system, Ecological Engineering 54 (2013) 49-56.

[14] P. Arulazhagana and N. Vasudevan, Biodegradation of polycyclic aromatic hydrocarbons by a halotolerant bacterial strain Ochrobactrum sp. VA1, Marine Pollution Bulletin, 26 (2011) 388-394.

[15] P. Arulazhagan, N. vasudevan, I. T. Yeom, Biodegradation of Polycyclic Aromatic Hydrocarbon by A Halotolerant Bacterial Consortium Isolated from Marine Environment, Int J.Environ. Sci Tech 7(2010) 639-652.

[16] J. Wunbua, K. Nakhapakorn, and S. Jirakajohnkool, Change detection and identification of land potential for planting Krajood (Lepironia articulata) in Thale Noi, Southern Thailand, Songklanakarin J. Sci. Technol. 34 (2012) 329-336.

[17] W. G. Landis and. M. H.Yu, Introduction to environmental toxicology: impacts of chemicals upon ecological systems, third ed., Lewis Pub, 2004. 